UNITED STATES ATOMIC ENERGY COMMISSION

\section{CONCENTRATION OF C-2 SLAG}

By

W. G. Thomas

Photostat Price $\$ 1.80$
Microfilm Price $\$ 1.80$
Available from the
Office of Technical Services
Department of Commerce
Washington 25, D. C.

February 17, 1944

Hooker Electrochemical Company

Niagara Falls, New York

Technical Information Service Extension, Oak Ridge, Tenn. 


\section{DISCLAIMER}

Portions of this document may be illegible in electronic image products. Images are produced from the best available original document. 


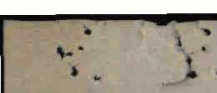

1735

\section{UNCLASSFFED}

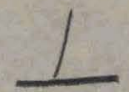

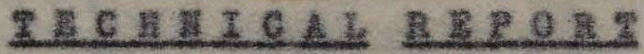

Subaltted bys

W. O. Thomes, Captasn, C. E. I7 Toleruary 1914

Work Doae byt

$$
M-456 \frac{21}{2}
$$

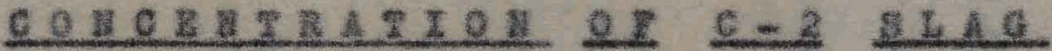

Ur, J. B. Desnblodson of Assoetates Resserch Leboratertes Hoolter Hectrochealienl. Co. Negera Falls, S. I.

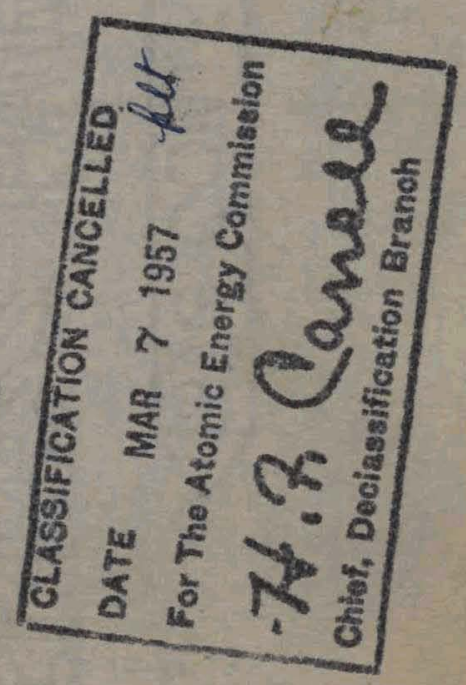

Hxilere Fugervilaton of:

T. Q. Thonsa, Captain, C. E.

R. L. Murrey; Hooker Liectroeboatcul Co. 


\section{$\because \quad r$}

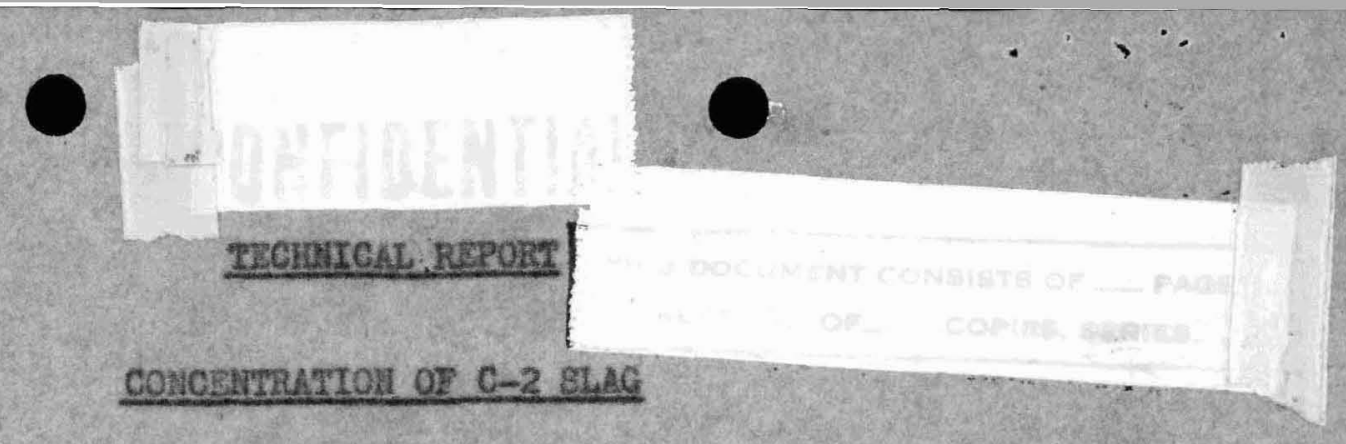

MUDax:

The boab reation slag produced at the BlectroYotallurgleal $X$ metal plant is at prosent divided into rloh $C-1$ Blag and lean $\mathrm{C}-2$ elas by meraly screoning through a 4 mesh wire

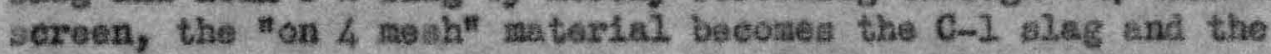
athra 4 sesh" bscomea the $\mathrm{C}-2$ slag. In the experisents eovered. by this report it wa found that tha coneentratlen of the 2 eas C-2 olag could bo fachiftated by the use of a 20 mesh sereen for the alag separation in plase of the 4 wesh acreen, sis the 20 mesh ucreen reacved troublesone, sana11, hard lamps whoh gessed the 4 mesh soreen. Purthernore, it pas found that the additional. small lumps reraved by the 20 mesh screen were just as $x$ ch in $\pi$ mothl. as the Larger 3 amps which rake up the buik of tha $\mathrm{C}-1$ slag. The $\mathrm{C}-2$ alag fhleh bad been separated with the 29 sesh screen was resdily eoncentrated from 0.345 Mix content to $5.6 \%$ Ifs content, with no appreoteble loss of $4 \mathrm{x}$, by the use of the maste irydrechlorle and fron the Hooker P-1/S Plant. The quantity of veste hydrochlorie acid avallabie at the P-45 Plant at Mooker 1 s suffielent to eoncontrate from 65 to 80 tons of the $\mathrm{E}-2$ alag per month.

The Installation cost of the buliding and equipanent for the coneentration of a saxtuan of 80 tens of $\mathrm{C}-2 \mathrm{~s}$ ang pex month at IISC 1 s estimated to be f12,000-15,000, th the neeessary equip-

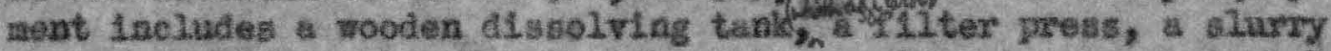
pusp, an acid pusp, and berrel handling equipment. Approxiastely two nonths wili be requlred for the completion of the Installation.

The operatins cost of this instalistion is estinated to be $\$ 1,200.00$ per month bused on thres aen, elght hours por dey, six days por reek.

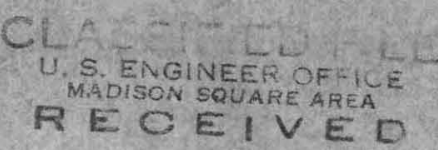

FEB 261044

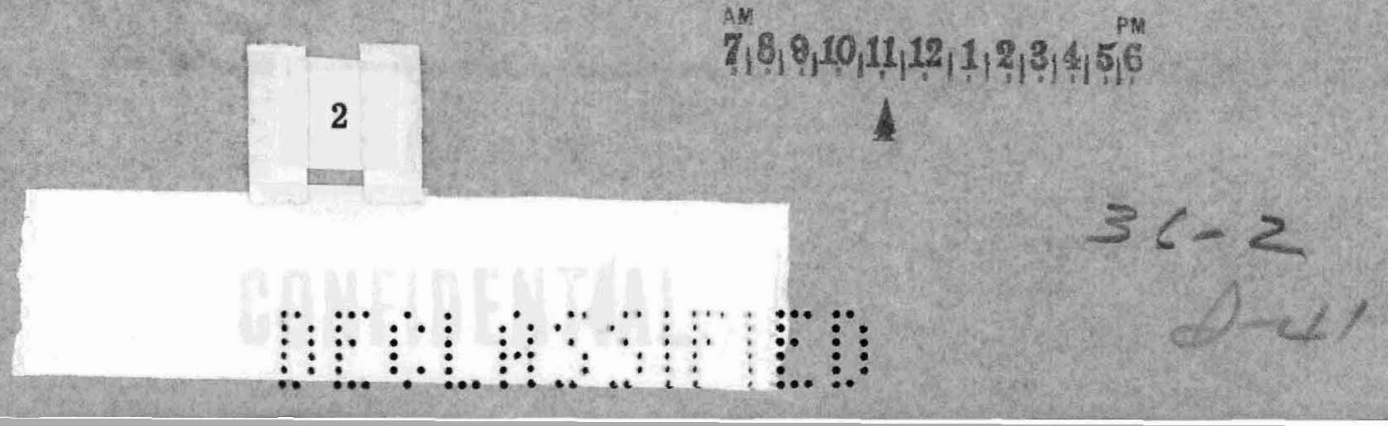




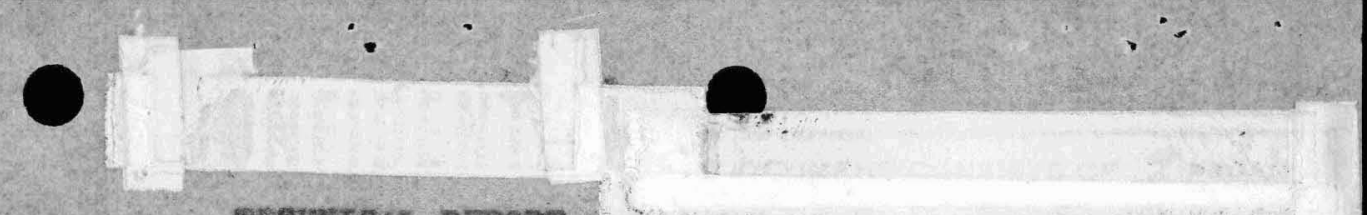

Pownzon RaPont

\section{Coscumartow op $\mathrm{C}-2$ SLAC}

\section{Intaovecrior.}

The reduetion of green sit to produce the $\mathrm{x}$ inetal. results in a resetion sise which is arbitrarily divided into two parte, $6-1$ alsg (ox or-4 mosh lumps) whob conteins $510 \%$ $X$ wetal and the C-2 Blag (or through- 4 wesh fines) which contains $-3 x \times$ wetel content. The $C-1$ slag 18 suitablo to ship to the $X$ intai recovery plant as produced but the $6-2$ slag is so Low is $X$ ewatent that, if it 1 s ahppod as produced, it civersely effects the produetion of the plant which has been set uy to recover the $X$ netal. from the glag. Henco, the poseluillties of concentruting the C-2 slag prior to recovery were investigated with the purpose of preventing adverse effect of the low eoneentration on the produetion of the recovery plaat.

\section{Since the bulk of the $\mathrm{C}-2$ slag $1 \mathrm{~s}$ agenesiun oxide} and exieiva oxide both of which cun be diusolved out by hydroehloric seld without dissolving the $\mathbf{z}$ wetei, and since the Corps of Baglneers have a plant at the looker Blectrocheaical. Compeny there waste bydrochloric seld 1 s produced in large guant1tues and where linestone anst be purehased to neutrallas the raste ald, a logienl upproach to the probles of conoentretion of the C-2 slag seered to 1 o in the use of this waste aejd. Fherefore, a geries of concentration experiments waze exranged. at the Hooker lieseareh Laboratorles, wil 1375 poundis of $\mathrm{C}-2$

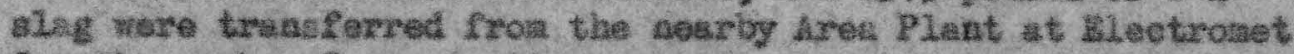
for the rork. Conceatration expertaente were rum using the waste scle frea the P- 45 Plant at Hooker.

II. RESUr, Awn conotustows.

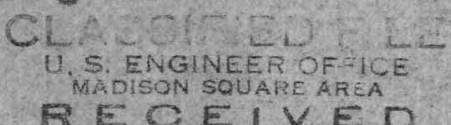

The rirst experiantal, mu showed that the san 17 \& 61944 iumps in the $\mathrm{C}-2$ siag which had bsen sereened tarough 4 -twesh

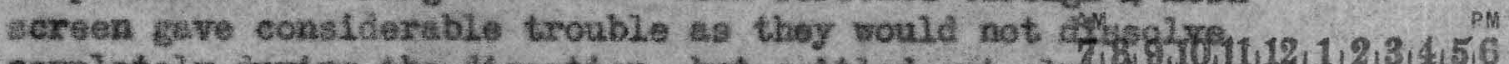

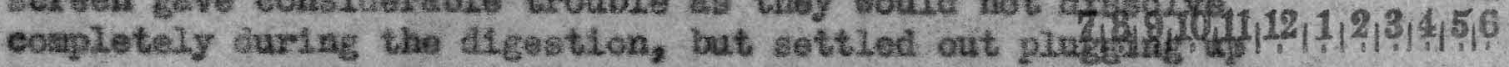
the tank outlot, and later Increased tho size ent weight of the fliter cake. To provent this trouble, the C-2 slag was ecreaned through a 20 aesh sereen. The on-20 aesh and through20 sesh portion were ebecked for lix eontent, as it was felt that the lumps from the $\mathrm{C}-2$ material should contein eonaliersbly nore $\mathbf{X}$ metul than the fines, Just as the lurgy $C-1$ matorial contains nore $X$ netal than the finer $C-2$ material. This proved to be the case as the on-20 lumps analysed elght tires as higb in $\mathrm{X}$ content es the throtigh-20 portlon. This scrsening of the $\mathrm{C}-2$ anterial produese amali lump: which contaln approximately the aane eoneontretion as the $C-1$ slaz. The $C-2$ slag which was seprrated using the 20 weah sereen was retilly concentrsted 
Technicel Report

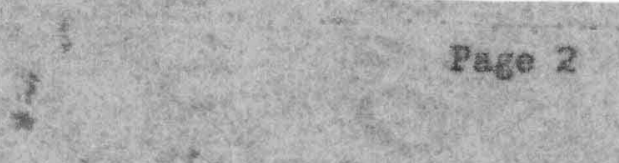

Fith the availsble vaste acld so suitsble Ux coneentration for feed to the reeovery plant.

Throe runs were arde to ceterwine the degree of concentration poosible with the svaliable vaste ecid on the C-2 sles phich had been sepurated with the 20 iaen sereen. is the tuble below hows, an increase in concentration of approximately seven tiaes was obtained using a method spiliesble to plant operations. (tun $f(4)$. This produced a wet flitar coke oontalning $5-6 \% \mathrm{x}$ and about $40 \%$ solsture from C-2 alog flnes of $.84 \% \mathrm{X}$ content. It 1 a the unitexstanilas of the writer that this is a sultable feed for the recovery plent. Antlyses of the filtrate from two of these runs showed that no $\mathrm{X}$ watal wos $20 \mathrm{st}$ in the flitrete. In vien of the wuccass encountered in diviaing the reaction alag into $\mathrm{C}-1$ and $\mathrm{C}-2$ portions using a 20 mosh screen, it wus dectded to deternine the rosults obtainable using even finer screons. Sepurations were asde usins 40 -mesh and 60 -wesh screens. However, nelther gave such lmprovesent over the separation obteined uging the 20 -wesh rereen and the poreening turvagh the flater sereens proved to be conelderably wore diffleult than through the 20 -rask.

III. Rgcotrasmañons.

\section{It is reconaended thats}

1. The neceseary lastalistion be mede imedistely st the Hookar P-45 Pleat for the concentration of $\mathrm{C}-2$ slag ond that the $\mathrm{C}-2$ slag from ell metal. reduction plants be shigned to Hooker Bleetrocheal es 1 Cospary for concantratton before gotng to tha alag recovery plant provided the instsilethon and operating costs are justlfied by the savings at the eleg recovery plant.

b. That the siag at all reduction plants be screened through a 20 -aesh acreen insteed of the present. 4 -itesh sereen in sepereting it lato $\mathrm{C}-1$ and $\mathrm{C}-2$ sligg, whether it is to be concentrated st Hooker or not.

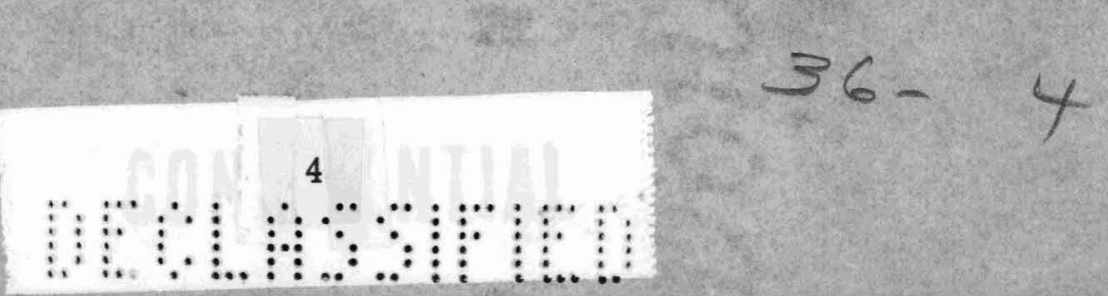


Techaical Report

Page 4

7. OPERATInG COSTS.

\section{c)}

CXCLE OR OPZRATTOHS

2 Men.

2 hours $\quad$ Dump $20 \mathrm{bble}$, st $275 \mathrm{Lbs}$. asch of sereened slag into tank and add 1600 galis. of water and start agitator.

Overnight

Ran in 2900 gals. of ruste acid.

30 nimutes

Agitate until all discolves.

30 minutes

Add $150-2001 \mathrm{~b}$, alag to sdjust pli to 7.0 (test with peper).

3 hours

Milter, wash, and alrbilow the cake.

2 howrs

Durig eake and bbl. ( 850 1b.) ( 3 bbls. of 300 if each).

8 houro/day

Plus one nan to load and unioad barrels.

\section{OPEZATIOA COS2 ESTHATS}

3 aen, 48 hours per week, \$1.20 per hour average.

Direct Labor $3 \times 1.20 \times 8 \times 26=8748$ pers month.

Overhead ( $40 \%$ of direct 1abor) $=\$ 300$ "

Halatenance

$\$ 100 *$ *

Stank, power and vater

152 " "

TOTAL. $61,200 *$ " 
Technieal Report

Page 5

VI. MXX MATERTAL, BATAAMCES.

\section{RUI NO. 4}

Wi. of Feed $=191$ 1bs.

Ux Cone, $=0.84 \%$

Mx Content $=191 \times .0084=1,601 \mathrm{bs}$. of $\mathrm{Mx}$

Wt. of tails $=291 \mathrm{bs}$. (wet)

$$
=29 x \cdot 586=17 \text { 1bs. }(\mathrm{dry})
$$

Mx Cons. $=9.87 \%$

Mx Content $=27 \times .0987=1.68$ 1bs, of $\mathbf{M x}$

$$
\text { \% Recovery of } \mathrm{Mx}=\frac{1.68}{1.60}(200)-105 \%
$$

\section{RUM 1 NO. 5}

Feed $=173$ Lbs, with $0.84 \% \mathrm{Kx}$

$$
173 \times .0084=1.452 \mathrm{bs} .
$$

Tatls $=51 \times \cdot 51=26$ 1bs, (ary) with $6.63 \% \mathrm{Mx}$

$$
\begin{aligned}
& 26 \times .0663=1.72 \mathrm{ux} \\
& \frac{1.72}{1.45} 9(100)=119 \% \text { recovery. }
\end{aligned}
$$

(Probably off due to difficulties of sampling of the nonhomogenoous heads and talls.)

Samples of the filtrates from both runs on nalyses showed no IIX content. 


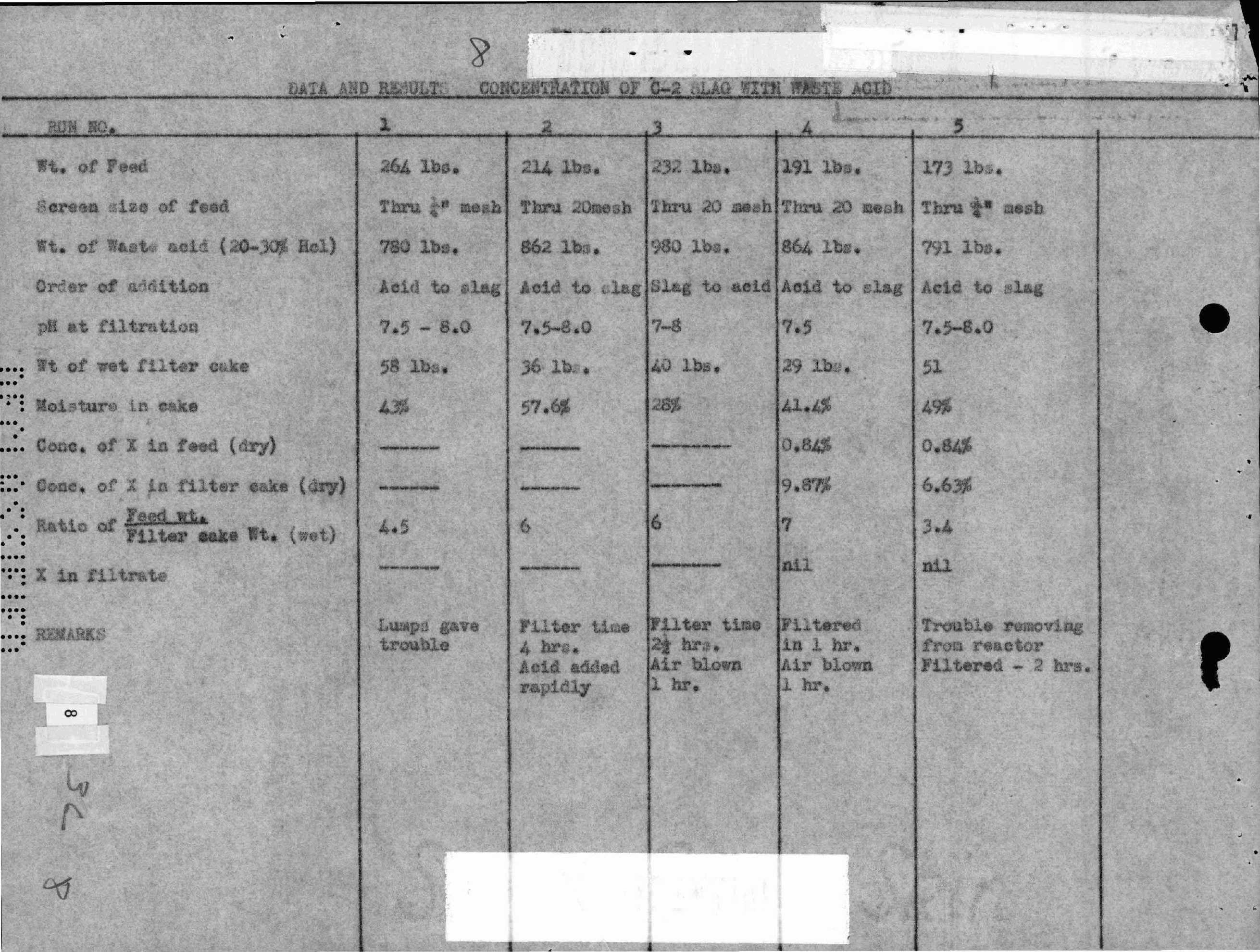




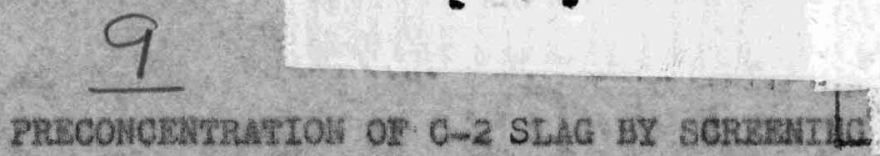

(Results of further screening of C-2 slag which was originally separated from the C-1 slag with a $\frac{1}{4}$ " mesh screen)

\section{Eith 20 nesh sexeen}

$\begin{array}{ll}\text { On } 20 \text { wezh } & 21.2 \% \text { by wt. } \\ \text { Thru } 20 \text { aeah } & \frac{78.8 \%}{100 \%} \text { " }\end{array}$

\section{X concentration.}

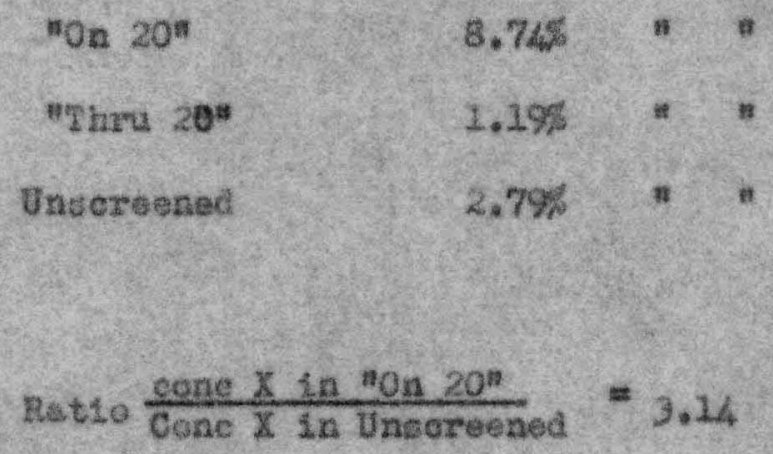

\section{\#ith 40 and 60 menh soreens}

$\begin{array}{lr}\text { On } 40 \text { mesh } & 15.4 \% \\ \text { Thru } 40 \text { on } 60 & \frac{2^{\frac{1}{3}} \cdot \frac{48}{2}}{1007}\end{array}$

\section{$X$ concentrestion}

$\begin{array}{ll}\text { "on } 40 \text { on } & 4.04 \% \\ \text { "On } 60 \text { " } & 2.04 \% \\ \text { "Thra } 60 " & 0.23 \% \\ \text { Orlginal } & 0.84 \%\end{array}$

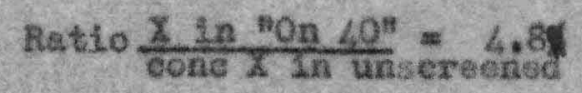

